\title{
THE HISTORY OF THE LIMIT STATE DESIGN METHOD
}

\author{
A natoly V. Perelmuter \\ SCAD Soft Ltd., Kyiv, UKRAINE
}

\begin{abstract}
This paper analyzes the 70-year history of development of the limit state design method (LSDM ) focusing on the fundamentals of the design codes based on this method and considers proposals for improving the LSDM and its justification. It was also noted that the reaction of the system in any of its fixed states is not always sufficient to assess the reliability of the system, and therefore it is necessary to analyze the rate of loss of resistance of load-bearing structures. However, probabilistic considerations were not enough due to the lack of reliable statistical data in the area of extreme sections of the distribution curves and a number of other circumstances (features of control procedures, different behavior of the material in the structure and in the samples, etc.). This paper analyzes some fundamental issues that should be solved when developing the method for the nonlinear analysis.
\end{abstract}

Keywords structural design, limit state design method, computing, reliability theory.

\section{О РАЗВИТИИ ОСНОВНЫХ ИДЕЙ МЕТОДА РАСЧЕТНЫХ ПРЕДЕЛЬНЫХ СОСТОЯНИЙ}

\author{
А.В. Перельмутер \\ SCA D Soft Ltd., Киев, УКРАИНА
}

\begin{abstract}
Аннотация. Анализируется 70-тилетняя история развития метода расчетных предельных состояний (МРПС). Основное внимание уделено принципиальным положениям нормативных документов, которые основаны на этом методе. Рассматривалась история развития основных положений МРПС и их представления в нормативных документах, указываются работы, в которых выдвигались предложения по совершенствованию МРПС, и его обоснованию. При этом отмечено, что реакция системы в каких бы то ни было фиксированных ее состояниях не всегда является достаточной для оценки надежности системы и указывается на необходимость анализа темпа потери отпорности несущих конструкций. Рассмотрен отход от использования только вероятностных соображений, который произошел ввиду отсутствия надежных статистических данных в области крайних участков кривых распределения, а также с учетом ряда других обстоятельств (особенности контрольных процедур, различное поведение материала в конструкции и в образцах и др.). Анализируются некоторые принципиальные вопросы, которые следует решить при развитии метода в нелинейном варианте анализа.
\end{abstract}

Ключевые слова: проектирование конструкций, метод предельных состояний, расчеты, теория надежности.

\section{INTRODUCTION}

This year marks 70 years since the release of the fundamental book [1], where the limit state design method was presented to the engineering community, which was soon adopted as the basis for design codes. This method became an ideological basis for the formulation of the structural reliability requirements, and in this capacity it was used in the reliability theory that appeared in the 50s. The issues of the formation and development of the theory of reliability of buildings and structures have been repeatedly considered and analyzed by various authors [2], [3], [4], but the limit state design method itself has not been subjected to such analysis, although the history of its development is no less informative.

The practical implementation of the ideological basis of the method, which was related to a 
number of not always explicitly formulated assumptions, required additional research to substantiate them. In some cases, this kind of research has indeed confirmed the accepted approach. However, it often led to the conclusion that adjustments and clarifications were in fact necessary.

That is actually what the development process and the resulting procedures for improving the codes were all about. In this paper, we will consider some fundamental issues related to the refinement or correction of the basic ideas of the limit state design method, both taken into account in the mentioned series of design codes, and those under discussion [5], [6]. We mainly consider the Ukrainian and Russian experience, although it should be noted that many of the issues discussed below have found their solution in Eurocodes [7], often in a different form.

\section{METHODS}

This work is based on the analysis of various sources describing an approach to the problem of design justification of reliability and safety of buildings and structures using the limit state design method. It focuses on the fundamentals of the design codes which indicate the goals and determine the approach for solving this problem. The paper considers the history of their development and works with proposals for improving the LSDM and its justification [8, 9, 10], as well as the ways of their implementation in SCAD, LIRA, MicroFE. After all, it is the software implementation that is one of the best ways to identify inconsistencies and contradictions, if there are any in the codes.

One of the important sources of a critical approach to standards and their assessment was a design code I have a developed [11] devoted to the general principles of ensuring the reliability and safety of buildings and structures, as well as to the implementation of standard requirements in SCAD [12].

\section{RESULTS}

The issues discussed below are related to certain key aspects of the limit state design method. $\mathrm{N}$ ot only do they reflect the history of its formation and development, but also highlight the problems that need to be resolved.

The limit state design method is based on the following:

- of all possible technical states of the operated structure, only its limit states are analyzed;

- the general safety factor is represented by a product of partial factors, each one related to a certain physical phenomenon (loading, resistance, simplification of the design model, etc.);

- values of the partial safety factors are substantiated by statistical data on the variability of the corresponding physical parameters.

Let us consider some clarifications, modification and adjustments of the design codes. In total, since 1954 there have been six versions of the fundamental design code [13], [14], [15], [16], [17], [18] and some changes were introduced into their texts.

\section{Analysis of F ixed States of the System}

This method is based on the idea of performing a detailed analysis only for the limit states of the structure, while almost completely ignoring all other structural states, which, by the way, correspond to the majority of the operating time. It is at this time that many destructive changes occur (corrosion, fatigue accumulation, erosion, etc.).

Besides the known advantages, this approach has a serious disadvantage. If, for example, we consider the strength condition as one of the limit states and design the structure ensuring that this condition is not violated during the entire service life with a certain degree of confidence, we know almost nothing about the level of actual stresses corresponding to the normal (non-limit) state under the most frequent operating conditions. 
The states of the structure most frequently occurring under the operating conditions usually define its durability. However, the following structures can turn out to be almost equivalent according to the limit state analysis:

- a dam with a normal loading not far from the allowable value (for example, $80 \%$ of the design value),

- a chimney with a very rare design load and a normal loading equal to, for example, $15 \%$ of the design value.

Since most of the structural lifetime corresponds to the normal operating states, during which the destructive changes occur in the material (for example, corrosion processes or the fatigue accumulation), then in order to ensure operational reliability and durability it is important to perform the analysis of a structure that is normally operating and is far from exhausting its strength and stability.

A ccording to [19] there is a certain failure due to the loss of design control over the structure during its transition from a "healthy" (normal, operational) state to the limit one. It would seem that the serviceability limit state checks could eliminate this methodological failure, but the thing is that these are limit states as well, i.e. correspond to rather rare extreme structural and environmental parameters.

It should be noted that the reaction of the system in any of its fixed states is not always sufficient to assess the reliability of the system under variable interaction with the environment. The simplest example of comparing two systems $S_{1}$ and $S_{2}$, a graphic illustration of which is shown in Fig. 1 in the form of a relationship between the reaction $F$ and the intensity of the action $P$. Even a slight increase in $P$ in the $S_{1}$ system leads to a sharp increase in the reaction, up to its critical value, which is not observed in the $S_{2}$ system.

Hence, a proposal appeared to introduce the concept of the limit behavior of the system, which limits the gradient $\mathrm{g}=\mathrm{dF} / \mathrm{dP}$ [20].

It is easy to see that the gradient $\mathrm{g}$ characterizes the rigidity of the system, i.e. we are dealing with a new limit state in the form of limiting the rate of possible decrease in the rigidity of the system (loss of its resistance).

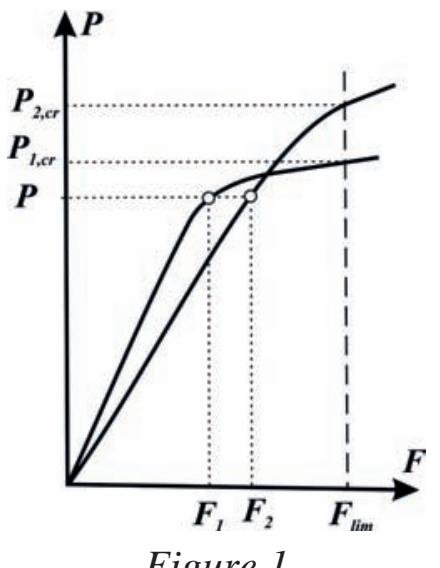

Figure 1

In fact, this approach is almost always used in experimental studies of the operation of a structure, where it is difficult (and sometimes impossible) to accurately capture the limit state and the experiment stops when, for example, deflections start increasing rapidly.

\section{Statistical J ustification of the Design Parameters}

Since about the mid-60s, when the theory of reliability of building structures was actively developed, the limit state design method has been perceived as a tool for ensuring reliability. This was clearly indicated in GOST 27751-88. In accordance with Sec. 1.5 of this document, the limit state design is performed in order to ensure the reliability of a building or structure throughout the entire service life, as well as during the construction. The design values of loads or forces caused by them, stresses, deformations, displacements, crack opening widths must not exceed the corresponding limit values established by the design codes.

Since it is not possible to determine the reliability of the entire structure due to its extreme complexity, the reliability of the entire structure is determined by the reliability of its individual members. In fact, element-byelement analysis is performed, and the required reliability (probability of failure-free operation) of each individual element is provided. This 
element-by-element check according to the weakest-link method assigns the entire structure a topology of series-connected members, which in reality is not always the case. As a result, it is impossible to determine the actual value of the reliability of the designed structure.

This fact reflects a logical contradiction in assessing reliability using the limit state design method, since reliability is the ability to fulfill the functional purpose, and it is normalized not by this indicator, but by the absence of failures.

The reliability of building structures is determined using the probabilistic approach [21], [22], [23]. Moreover, it is widely believed that only the probabilistic description of the structural behavior makes it possible to assess the reliability of buildings. A nd the limit state design method itself was created under the prevailing influence of the problem of random variability of the loading and resistance parameters of the structure. For example, when the method had just been created, the design values of the resistances were treated as statistically justified. However, due to the lack of reliable statistical data in the area of extreme sections of the distribution curves and a number of other circumstances (features of control procedures, different behavior of the material in the structure and in the samples, etc.), in 1971 it was decided that probabilistic considerations were not enough to justify the design resistances [9].

This process turned out to be uncontrollable, and today it is already difficult to say which of the partial safety factors, and to what extent, are not statistically justified, but are based on other considerations.

\section{Reliability M anagement}

The reliability requirements should obviously be formulated based on the actual facility (its importance, etc.). Hence, a reliability management mechanism is required.

In fact, management is implemented by using different design values for the considered actions (the higher the importance the higher the value), and assuming different service life. The differentiation of the approach was used in the limit state design method from the very beginning and was reduced to taking into account the differences between permanent and temporary structures, and to the use of various design combinations of loads (main, additional, special).

The direct mechanism of reliability management was introduced in 1981 and it lied in allowing for the importance of the structure, while all facilities were divided according to this criterion into three classes [24]: increased, normal and reduced levels of importance. The purpose of such a differentiation of reliability is the socioeconomic optimization of resources used in construction taking into account the expected consequences of failure and the cost of construction. And the mechanism for allowing for the importance level was implemented in the form of another partial safety factor, which was introduced as a factor to the load effect.

Differentiation by class of importance was also used in relation to other aspects of ensuring the reliability of structures. Importance classes are involved, for example, in the engineering research and even in the applied calculation procedure (the linear spectral analysis or the analysis based on accelerograms), as is customary when checking the seismic response. In relation to a structure or a structural member, reliability is considered as the ability not to reach a limit state over a certain period of time. A nother parameter used in the reliability management is the design service life of the structure. It determines that during this period of time, the structure or its part should be used for its intended purposes with the necessary maintenance, but without large-scale repair work. This parameter is taken into account when developing measures to ensure the durability of structures and their foundations [18] or when assigning design values of climatic actions, as provided, for example, by the codes of Ukraine [11].

\section{Post-critical B ehaviour of a Structure}

Considering the limit state as a critical and absolutely unacceptable design case, which underlay the classical version of the limit state design method, did not take into account the 
possibility that the transition through the boundary outlined by the description of the limit state is not always fatal (Fig. 2.a). There are the so-called reversible limit states, which disappear once the actions that have caused them are removed (Fig. 2.b). Deflection of an elastic structure is a typical example. For such states, it can be useful to establish not only the defining boundary, but also the time period during which the structure can be outside this boundary.

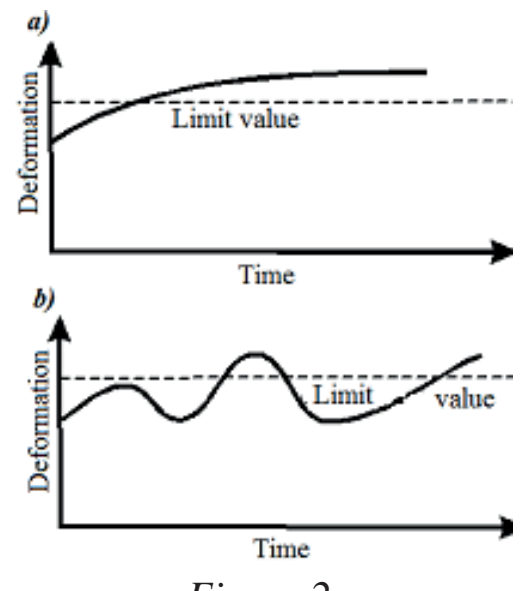

Figure 2

The design of highly directional antennas can serve as a typical example here, where the angular displacement is normalized, and its value directly determines the quality of radio transmission. If you agree to sacrifice this quality, for example, within $1 \%$ of the time, the wind load, under the action of which the deflection angle is determined, is reduced by 2 3 times.

However, consideration of a system in its postcritical state can be related not only to the reversible limit states. Thus, in the classical approach the ultimate limit states were assumed to be absolute and their violation was not allowed. This postulate was quickly violated in the theory of seismic protection.

A new definition of the concept of "limit state" was formulated in [25]. It was different from the classical one, where for the ultimate states it was identified with the impossibility of further operation of the facility. Some buildings damaged by an earthquake can still be operated after repair and restoration, so it was proposed to assume that they have not reached their ultimate limit state yet. The transition to multilevel seismic analysis, which implemented this innovation, pointed to the problem of formulating a series of limit states that differ in the degree of conservation and the possibility of using the facility under seismic actions of varying intensity (more precisely, different recurrence [26]).

\section{Nonlinear Analysis Problems}

The method was created at a time when all verification calculations were performed in a linear formulation, which significantly affected the technical side of the method. The widespread use of computer technology and the related increasing spread of nonlinear analysis indicated a number of problems that were not taken into account at the time [27].

Thus for all linear systems, the main inequality of the limit state design method is presented in a form that provides for the possibility of a separate description of the parameters of the structural behavior, depending on the load, and the parameters that determine the strength properties of the structure

$$
\psi \gamma_{n} \gamma_{f} F_{n} \leq \gamma_{c} \gamma_{m} R_{n} .
$$

However, this is not always feasible in nonlinear problems, where the uncertainties of the impact model and the resistance model can be closely related, for example, through the use of the same physical relationship $\sigma=f(\varepsilon)$. This issue occurs in some linear problems as well. Thus, for example, the reactions of the soil and its resistance cannot be considered separately, since the active pressure of the soil and its resistance depend on the action.

Checks of fulfillment of the inequalities usually operate not with the values of the design loads $F_{d}$, but with the values of the effects from these loads $S_{d}$ (forces, stresses, displacements, etc.). One of the classical postulates of the limit state design method was the assumption of a deterministic and linear relationship between the action $\mathrm{F}$ and the effect of this action $\mathrm{S}$. On its 
basis, the partial safety factor for load was attributed to the effect of the action (stress, displacement, internal force, etc.). It was shown in [28] that this postulate is not always applicable.

Probabilistic characteristics $S_{d}$ are often identified with the probabilistic characteristics of the load $F_{d}$, using the safety factor $\gamma f$ for $S_{d}$, the value of which is determined by the properties of the load. However, the effect of the action is a function of the action itself and the design model, therefore its variability $V_{s}$ may differ from the characteristics of the variability of the action itself $V_{F}$. Such a coincidence always takes place for a linear relationship between $S$ and $F$, but it will no longer exist for a nonlinear relationship $S=f(F)$. In this case the relationship between the rate of increase in stresses or other similar factors, which can be higher or lower than the rate of change of the external action, plays an important role (Fig. 3).
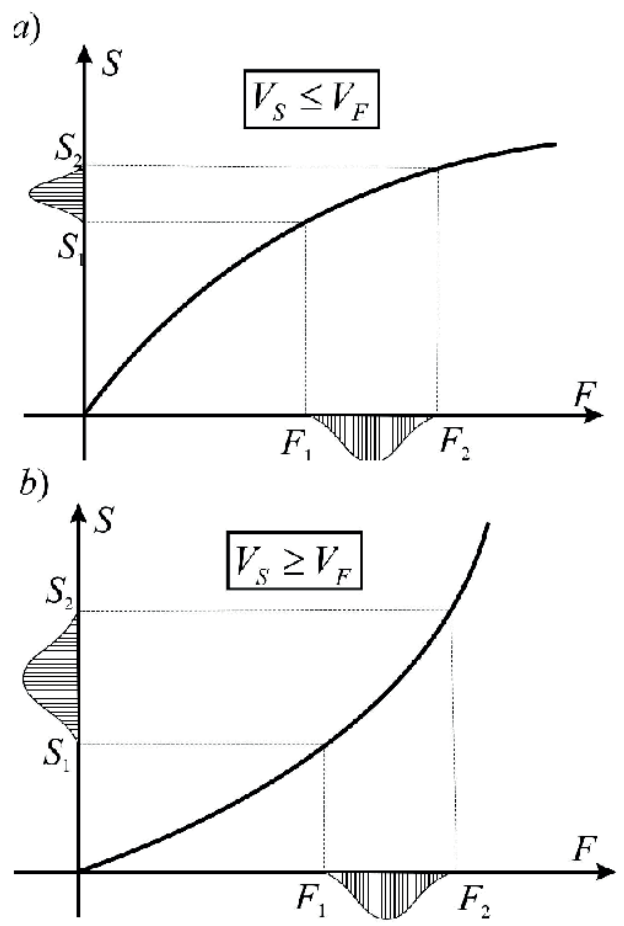

Figure3

A n even more complicated situation arises when the transition from $\mathrm{F}$ to $\mathrm{S}$, even with a linear relationship $\mathrm{S}=c F$, is such that the influence coefficient $c$ turns out to be a random variable. A fairly typical case illustrating the last statement is the case of crane actions [28], when the design combination of loads (and the characteristics of the spread of their values) or the design combination of internal reactions of the system (forces, stresses, displacements) do not coincide. The transition from $F$ to $S$ takes place under the influence of a number of other random parameters, such as the random positions of the crane bridge on the crane girder and the trolley on the crane bridge. Consequently, the characteristics of the spread of the load values do not coincide with the similar characteristics of the load effects, which should actually lead to the use of different values of the safety factor for load (more precisely, for the load effect) when considering different problems.

\section{Special Limit States}

In his work [8] N.S. Streletsky pointed out two postulates that are inherent in the limit state design method: (a) the analysis is related to a failure-free state of structures and (b) an adequate structure immediately becomes inadequate the moment it passes the limit state. Ukrainian and Russian standards did not consider accidental situations for a long time, proclaiming that the considered limit states correspond not to accidental, but to preaccidental situations. The introduction in 2010 of the third group of special limit states in GOST R 54257 was an attempt against the inviolability of these postulates.

It is usually assumed that special limit states caused by special accidental actions (impacts, explosions, etc.) occur in the form of a local destruction. These special limit states are studied in order to assess the possibility that such local destruction will not lead to a general collapse or an unacceptably large number of collapses.

In fact, we are dealing with the analysis of structural robustness, although this problem reduced to checking the ability of a damaged structure to perform its functions (possibly with some loss of quality) has been replaced by 
checking for the absence of progressive (disproportionate) collapse. It should be noted that unlike the usual ultimate limit state analysis, where the local bearing capacity of a design section is analyzed, the concept of "bearing capacity" must be given a broader meaning and we must consider the structure as a whole when it comes to checking special limit states. However, it is much more difficult to formulate the criterion for reaching the limit state of an entire structure than of its individual section, and perhaps this is the reason for the indicated substitution.

The fact that this approach is not always applicable for the problems of robustness can be demonstrated with an example of the structures of gas holders, oil reservoirs etc. If such a structure is damaged, for example, a small crack appears, collapse will not occur, but the loss of integrity will lead to leakage of the stored substance, and therefore to the loss of the structural function. This is a vivid example that the absence of progressive collapse does not yet guarantee robustness.

The current state of the problem of analyzing special limit states does not yet have a clear conceptual justification. Such documents as SP 296.1325800.2017 [29] have only identified the problem and given some prescription recommendations. A common approach that is applicable not only for buildings is yet to be developed.

W e, apparently, need a document like the General Safety Rules in the nuclear industry, which uses, for example, a principle of single failure and provides only rules of behavior for the beyond design basis accidents (notification, evacuation etc.), but not a requirement to resist them.

The very concept of special action has to be clarified. The current rule that does not consider the simultaneous action of two or more special loads is based on the fact that such actions have a very short duration and the probability of coincidence of such intervals is negligible. However, even a very short action can lead to long lasting consequences, which might still be present when another special action occurs.
Actions arising from the wetting of subsidence soils or their subsidence in areas of mine workings and in karst areas can serve as an example. For example, an earthquake may well occur in the mined territories of $\mathrm{K}$ uzbass.

\section{Vulnerability Assessment}

The limit state design method assumes that all loads and actions that may occur during the life cycle of the designed facility are considered and taken into account. However, besides the predictable loads, there is always a possibility of an accidental action not predicted neither by the design codes nor by the designer. American economist Nicolas Nassim Taleb called similar events "black swans" ${ }^{1}$. From the point of view of these surprise events vulnerability of the design object is an important characteristic.

Vulnerability characterizes a possibility of causing damages of any nature to the considered system by some external means or factors. Vulnerability is closely related to a well-known characteristic of "robustness" and to an additional characteristic - "mobilization" recently suggested in [30]. The robustness is considered as in a manner spatial characteristic which shows how a local perturbation spreads throughout the space of the system and whether this local destruction can get a disproportionately large development "in breadth".

Mobilization shows the readiness and ability of the system to react to a local in time (pulse) unexpected perturbation. In both cases, the perturbation can be so strong that we would have to deal with its consequences, and its nature is such that it is not possible to predict the moment and place of its occurrence, as well as other quantitative characteristics. N oticeable absence of the structural mobilization, as well as insufficient robustness, should serve as a reason for the increased attention and use of some protective measures.

\footnotetext{
1 Juvenal said: "rara avis in terris nigroque simillima cygno"(lat.) - a "good man is as rare, as a black swan", since there was a hypothesis that all swans were white. It had been correct until a black A ustralian swan was discovered in 1700.
} 


\section{DISCUSSION}

The limit state design method is constantly developing, allowing and undergoing improvements not only in its purely technical aspects, but also in some ideological foundations. At the same time, a number of issues related to such changes remain unresolved. We will consider only some of them.

A) The issue about the relationship between probabilistic and deterministic justification of partial safety factors is one of the fundamental ones. It is generally accepted that safety margins are intended to prevent the five main causes of failure:

(1) L oads are greater than anticipated.

(2) M aterial has poorer properties than anticipated.

(3) The theory of the considered failure mechanism is imperfect.

(4) Possible unknown and therefore unaccounted for causes of failure.

(5) Potential human errors (e.g. in the design).

The first two options can, generally speaking, be classified as variability in design parameters, so they are available for probabilistic estimation. The last three types of failure causes operate not with probabilities, but with possibilities, they are difficult or even impossible to represent in probabilistic terms, and therefore they belong to the category of non-statistical uncertainty.

And if we assume that the safety margin is intended to compensate for the main sources of failure, then we can assume that in the first two cases it is preferable to rely on probabilistic information. The main advantage of assigning safety factors on a non-statistical basis concerns the other three sources of failure. Therefore, the probabilistic approach should only be one of several tools for assessing reliability, and both approaches have their advantages, so they cannot be considered as mutually exclusive.

B) The group of special limit states introduced quite recently, where many things remain unclear, requires serious improvement. For example, the unusually widely understood tendency to use the method of exclusion of a structural member to test the possibility of progressive collapse, when it turned out that all statically determinate design models were impossible to use, raises many questions. This is a typical example, when they are trying to replace the method of analyzing a dangerous situation with a conditional technique having a limited scope (not explicitly specified).

C) In the design practice, the issues of analysis of load-bearing structures equipped with protection systems (seismic protection, fire protection, overload protection, etc.) are increasingly raised. For a load-bearing structure, these systems change the nature of action, their intensity and statistical properties. Both issues of checking the load-bearing capacity of a protected structure (what is the safety factor for load) and checking the protection system itself, which should have a certain guaranteed operability margin (what are the partial factors for such a check).

There are other problems related to the development of the limit state design method as well. In particular, the limit states arising in the course of long-term degradation (corrosion, wear, minor mechanical damage) remain unknown, which we try to analyze only at the end of the process, when the structure is on the verge of failure. In particular, a problem formulation of limiting the degradation rate is possible and, consequently, the problem of ensuring reliability for this indicator, including checking the limit state for violation of this rate.

\section{CONCLUSIONS}

For construction facilities, the issues of ensuring their existence and use for their intended purpose over the past decades have been interpreted as a subject of study of reliability problems. And the issues of practical implementation of the recommendations developed by the theory of reliability, which are the essence of the limit state design method, remained outside the scientific analysis. Consideration of the history of improvement of 
the limit state design method shows that the method itself should be a subject of special consideration.

There has to be a clear formulation of the main provisions of the method, taking into account a number of new circumstances that are dictated by modern design practice:

- more frequent use of nonlinear analysis;

- limited and uncertain data on the expected operating conditions of the structure, when probabilistic methods are not applicable;

- using additional information that is available during the analysis of the behavior of existing structures (repair, restoration);

- the ability to use risk analysis when considering non-standard situations.

These and other similar issues should have become a subject of a specially organized scientific discussion, similar to the one that took place in the early seventies on the initiative of N.S. Streletsky at M GSU [31].

\section{REFERENCES}

1. Baldin V.A., Goldenblat I.I., Kochenov V.I., Pildish M.Ya., Tal K.E. Calculation of Building Structures According to the Limit States, M .: Stroyizdat, 1951 - 371 p.

2. R andall F.A. Historical N otes on Structural Safety // Proc. A mer. Concrete Inst., Vol. 70, 1977, pp. 669-679.

3. Elishakoff I. Essay on reliability index, probabilistic interpretation of safety factor and convex models of uncertainty // Reliability Problems: General Principles and Applications in Mechanics of Solids and Structures (F. Casciati and J. B. Roberts, eds.), Springer, 1991 - pp. 237-271.

4. Raizer V.D. Essay on the Development of the Theory of Reliability and Design Standards for Building Structures // Seismic Design. Safety of Structures, 2014, No. 2, pp. 29-35.

5. Perelmuter A.V. Selected Problems of Structural Safety and Reliability. 3-rd edition, revised and updated. - M.: ASV Publishing House, 2007. - 256 p.

6. Perelmuter A.V., Kabantsev O.V. Pichugin S.F. Fundamentals of the Limit State Design Method - M .: SCAD Soft, ASV , 2019. - 240 p.

7. Gulvanesyan Kh., Kalgaro Zh.-A., Golitski M. Designers' Guide to Eurocode 1990: Basis of Structural Design - M.: M GSU, 2011. - 258 p.

8. Streletsky N.S. Priority Issues of the Development of the Limit State M ethodology // Development of the Limit State Design Method. - M.: Stroyizdat, 1971. - pp. 5-37.

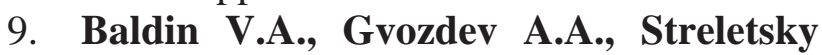
N.N., B at A .A., E fimov M .G ., L yalin I.B ., Mitkheev V.V., Otstavnov V.A., Tal K.E. To the release of SNiP II-A.10-71 "Structural Components and Foundations. Fundamental Design Principles" // Structural Mechanics and A nalysis of Constructions, 1972, N 0.4. - pp. 56-59.

10. Otstavnov V.A., Smirnov A.F., Rayzer V.D., Sukhov Yu.D. Importance of Buildings and Structures in the Design Codes // Structural Mechanics and A nalysis of Constructions, 1981, N 0.1. - P. 11-14.

11. DBN V.1.2-14-2018. General Principles of Reliability and Structural Safety of Buildings, Structures and Foundations - K : M inregionbud, 2018. - 29 p.

12. V.S. Karpilovsky, E.Z. Kriksunov, A.A. Malyarenko et.al. "SCAD Office. Implementation of SNiP in ComputerAided Design A pplications". 4-th edition M.: SCAD SOFT, 2018. - 567 p.

13. SNiP II-B.1-54. Main Recommendations for the A nalysis of Building Structures // Construction Rules and Regulations. Part II. Construction Standards - M .: Gosstryizdat, 1954 - pp. 41-48.

14. SNiP II-A.10-62. Building Structures and Foundations. Basic Design Provisions - M .: Gosstryizdat, 1962 - 44 p. 
15. SNiP II-A.10-71 "Structural Components and Foundations. Fundamental Design Principles" - M .: Stroyizdat, 1971 - 7 p.

16. GOST 27751-1988. Reliability for Constructions and Foundations. General Principles - M .: Standardinform, $1088-7 \mathrm{p}$.

17. GOST R 54257-2010. Reliability of Constructions and Foundations. Basic Principles and Requirements. - $\mathrm{M}$.: Standardinform, 2021. - $13 p$

18. GOST 27751-2014 Reliability for Constructions and Foundations. General Principles - M .: Standardinform, 2021 - 16 p.

19. Iosilevsky L.I. Practical Methods of $M$ anaging the Reliability of Reinforced Concrete Bridges - M. : SRC "Engineer", 1999. - $295 \mathrm{p}$.

20. Katyushin, V.V. Buildings with Steel Frames of $V$ ariable Cross-Section (A nalysis, Design, Construction) - M.: Stroyizdat, 2005. - 656 p.

21. Bolotin V.V. Application of the Methods of the Theory of Probability and the Theory of Reliability to Analysis of Structures. M.: Stroyizdat, 1982. - 351 p.

22. Rzhanitsyn A.R. Theory of Reliability A nalysis of Building Structures. - M.: Stroyizdat, 1978. - 239 p.

23. Raizer V.D. Probabilistic Methods in the A nalysis of Reliability and Robustness of Structures - M oscow: A SV , 2018. - 396 p.

24. Otstavnov V.A., Smirnov A.F., Rayzer V.D., Sukhov Yu.D. Importance of Buildings and Structures in the Design Codes // Structural M echanics and A nalysis of Constructions, 1981, N 0.1. - P. 11-14.

25. Bykhovsky V.A., Goldenblat I.I. Designing Reliable and Optimal Earthquake-Resistant Structures // Seismic Resistance of Buildings and Engineering Structures - M .: Stroyizdat, 1967 - pp. 4-9.

26. Perelmuter A.V., Kabantsev O.V. On Conceptual Provisions of Design Standards for Earthquake-Resistant Construction // V estnik M GSU, 2020, V. 15, I ssue 12 - pp. 1673-1684. DOI: 10.22227/1997-0935. 2020.12.1673-1684.
27. Perelmuter A.V., Tur V.V. A re we ready to move on to nonlinear analysis in design? // International Journal for Computational Civil and Structural Engineering, 2017. Vol. 13, No 3 - pp. 86-102.

28. Perelmuter A.V. Statistical Modeling of Crane L oads and Design Combinations of Forces // International Journal for Computational Civil and Structural Engineering, 2017. Vol. 13, No 2. - pp. 136-144.

29. SP 296.1325800.2017. Buildings and Structures. A ccidental Actions - $M$ : M inistry of Construction of Russia, 2017 $23 \mathrm{p}$.

30. Perelmuter A.V. Mobilization as a Characteristic of Reliability of Structures // International Journal for Computational Civil and Structural Engineering, 2017. Vol. 13, No 1. - pp. 86- 93.

31. Development of the Limit State Design Method / Collection of articles edited by Belenia E.I. - M .: Stroyizdat, 1971. - 175 p.

\section{ЛИТЕРАТУРА}

1. Балдин В.А., Гольденблат И.И., Коченов В.М., Пильдыш М.Я., Таль К.Э. Расчет строительных конструкций по предельным состояниям. - М.-Л.: Госстройиздат, 1951 - 371 с.

2. R andall F .A. Historical N otes on Structural Safety // Proc. A mer. Concrete Inst., Vol. 70, 1977, pp. 669-679.

3. Elishakoff I. Essay on reliability index, probabilistic interpretation of safety factor and convex models of uncertainty // Reliability Problems: General Principles and Applications in Mechanics of Solids and Structures ( $F$. Casciati and J. B. Roberts, eds.), Springer, 1991, - P. 237-271.

4. Райзер В.Д. Очерк развития теории надежности и норм проектирования строительных конструкций // Сейсмостойкое строительство. Безопасность сооружений, 2014, №2 - С. 29-35. 
5. Перельмутер А.В. Избранные проблемы надежности и безопасности строительных конструкций. 3-е изд, исправленное и дополненное. - М.: Изд-во Ассоциации строительных вузов, 2007. - 256 с

6. Перельмутер А.В., Кабанцев О.В. Пичугин С.Ф. Основы метода расчетных предельных состояний - М.: Издательство СКАД Софт, Издательский дом АСВ, 2019 - 240 с.

7. Гульванесян Х., Калгаро Ж.-А., Голицки М. Руководство для проектировщиков к Еврокоду 1990: Основы проектирования сооружений М.: МГСУ, $2011-258$ с.

8. Стрелецкий Н.С. К вопросу развития методики расчета по предельным состояниям // Развитие методики расчета по предельным состояниям. - М.: Стройиздат, 1971 - С. 5-37.

9. Балдин В.A., Гвоздев А.A., Стрелецкий Н.Н., Бать А.А., Ефремов М.Г., Лялин Н.Б., Михеев В.В., Отставнов В.А., Таль К.Э. К выходу СНиП II-А.10-71 «Строительные конструкции и основания. Основные положения проектирования» // Строительная механика и расчет сооружений, 1972, №4 - С. 56-59.

10. Отставнов В.А., Смирнов А.Ф., Райзер В.Д., Сухов Ю.Д. Учет ответственности зданий и сооружений в нормах проектирования строительных конструкций // Строительная механика и расчет сооружений, 1981, №1 - С. 11-14.

11. ДБН В.1.2-14-2018. Загальні принципи забезпечення надійності та конструктивної безпеки будівель, споруд, будівельних конструкцій та основ - К.: Мінрегіонбуд, 2018 - 29 с.

12. Карпиловский В.С., Криксунов Э.3., Маляренко А.A., и др. SCAD Office. Реализация СНиП в проектирующих программах. 4-е изд. - М.: Издательство СКАД СОФТ, 2018. - 567 c.

13. СНиП ІІ-Б.1-54. Основные положения по расчету строительных конструкций //
Строительные нормы и правила. Часть II. Нормы строительного проектирования М.: Госстройиздат, 1954 - С. 41-48.

14. СНиП II-А.10-62. Строительные конструкции и основания. Основные положения проектирования - М.: Госстройиздат, $1962-44$ с.

15. СНиП II-А.10-71. Строительные конструкции и основания. Основные положения проектирования - $\mathrm{M}$.: Стройиздат, 1971 - 7 с.

16. .ГОСТ 27751-1988. Надежность строительных конструкций и оснований. Основные положения - М.: Издательство стандартов, $1088-7 \mathrm{c}$.

17. ГОСТ Р 54257-2010. Надежность строительных конструкций и оснований. Основные положения - М.: Стандартинформ, 2021 - 13 с.

18. ГОСТ 27751-2014 Надежность строительных конструкций и оснований. Основные положения - М.: Стандартинформ, 2021 - 16 с.

19. Иосилевский Л.И. Практические методы управления надежностью железобетонных мостов - М.: НИЦ «Инженер», 1999. - 295 с.

20. Катюшин В.В. Здания с каркасами из стальных рам переменного сечения (расчет, проектирование, строительство) - М.: ОАО «Издательство Стройиздат», $2005-656$ c.

21. Болотин В.В. Методы теории вероятностей и теории надежности в расчетах сооружений - М.: Стройиздат, 1982 - $351 \mathrm{c}$.

22. Ржаницын A.P. Теория расчета строительных конструкций на надежность - М.: Стройиздат, 1978 - 239 с.

23. Райзер В.Д. Вероятностные методы в анализе надежности и живучести сооружений - М.: Изд-во АСВ, 2018 $396 \mathrm{c}$.

24. Отставнов В.А., Смирнов А.Ф., Райзер В.Д., Сухов Ю.Д. Учет ответственности зданий и сооружений в нормах проектирования строительных конструкций 
// Строительная механика и расчет сооружений, 1981, №1 - С. 11-14.

25. Быховский В.А., Гольденблат И.И. К вопросу о надежности и оптимальности сейсмостойкого строительства // Сейсмостойкость зданий и инженерных сооружений - М.: Стройиздат, 1967 - С. 4-9.

26. Перельмутер А.В., Кабанцев О.В. О концептуальных положениях норм проектирования сейсмостойкого строительства // Вестник МГСУ, 2020, Т. 15, Вып. 12 - C. 1673-1684. DOI: 10.22227/1997-0935. 2020.12.1673-1684.

27. Перельмутер А.В., Тур В.В. Готовы ли мы перейти к нелинейному анализу при проектировании? // International Journal for Computational Civil and Structural Engineering, 2017. Vol. 13, No 3 - C. 86102.
28. Перельмутер A.B. Статистическое моделирование крановых нагрузок и расчетные сочетания усилий // International Journal for Computational Civil and Structural Engineering, 2017. Vol. 13, No 2. - C. 136-144.

29. СП 296.1325800.2017. Здания и сооружения. Особые воздействия - М: Минстрой России, 2017 - 23 с.

30. Перельмутер А.В. Мобилизованность как характеристика надежности строительных конструкций // International Journal for Computational Civil and Structural Engineering, 2017. Vol. 13, No 1. - C. 86- 93.

31. Развитие методики расчета по предельным состояниям / Сборник статей пол ред. Е.И. Беленя - М.: Стройиздат, 1971 - 175 с.
Anatolii V. Perelmuter, Foreign member of Russian A cademy of A rchitecture and Construction Sciences, Doctor of Science, Professor; SCAD Soft, Ltd; Kyiv 03037, U kraine, 3a Osvity street, office. 1,2; phones: +38 0442497193 (91), +38 050382 1625, e-mail: A natolyPerel muter@sgmail.com. ORCID ID: 0000-00019537-2728
Перельмутер Анатолий Викторович, иностранный член РААСН, доктор технических наук, профессор; НПО СКАД Софт, 03037, Украина, г. Киев, ул. Просвящения, 3а, Офис 2; тел. +38 0442497193 (91), +38 050382 1625, e-mail: A natolyPerelmuter@sgmail.com, ORCID ID: 00000001-9537-2728 